IRA-International Journal of Education \&

Multidisciplinary Studies

ISSN 2455-2526; Vol.04, Issue 01 (2016)

Institute of Research Advances

http://research-advances.org/index.php/IJEMS

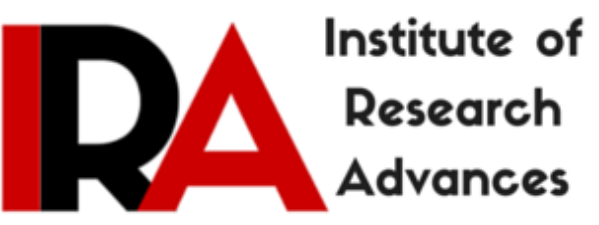

\title{
Portraying the Performing Artistes in Early India in the Context of Ancient Indian Scripters
}

\section{Dr. Ajesh T.V.}

Lecturer, Department of Sanskrit, NSS College, Pandalam, 689501- Kerala, India.

DOI: $\underline{\text { http://dx.doi.org/10.21013/jems.v4.n1.p8 }}$

\section{How to cite this paper:}

T.V., A. (2016). Portraying the Performing Artistes in Early India in the Context of Ancient Indian Scripters. IRA International Journal of Education and Multidisciplinary Studies (ISSN 2455-2526), 4(1). doi:http://dx.doi.org/10.21013/jems.v4.n1.p8

(C) Institute of Research Advances (cc) EY-NG

This works is licensed under a Creative Commons Attribution-Non Commercial 4.0 International License subject to proper citation to the publication source of the work.

Disclaimer: The scholarly papers as reviewed and published by the Institute of Research Advances (IRA) are the views and opinions of their respective authors and are not the views or opinions of the IRA. The IRA disclaims of any harm or loss caused due to the published content to any party. 
In ancient India theatrical performances were the main attractions for the people. Literary evidences prove that ancient Indian theatre is a comprehensive one and is a very popular for entertainment. Cultural arts like dancing, singing, puppet shows etc. were formulated and enacted from pre-Vedic period onwards. Historically, the origin of dance as a form of entertainment can be traced in the Indus valley period. The findings of archeological excavations from Mohenjo-Daro suggest that dance was very much popular in those days. 'Some of the earliest representations of scenes of dancing occur in cave paintings found in Mesolithic rock shelters. Subsequently, finds of sculpture and representations on seals from Harappan civilization (c. 2700- 1800 BCE) have been taken to represent dancers. ${ }^{, 1}$ The posture of grey slate figure of a male dancer from Harappa reminds of tāndava and supports the affinity between the male deity of Harappan culture and later Siva. It seems that Indus people were interested in theatrical art very much ${ }^{2}$

Some scholars hold the view that theatrical performances developed from the instinct of primitive peoples to imitate the action of people and nature around them. ${ }^{3}$ During their leisure they had cultivated various kinds of fine arts, music, dance etc. Further, it developed as theatrical art and it provides suitable jobs, artistic engagements and also a source of livelihood for men and women. Scholars suggest that performance tradition emerged probably from ritual contexts. A.L. Basham says, 'as in most other civilizations there is little doubt that the Indian drama developed from ritual miming song and dance. ${ }^{4}$ A.B. Keith also shares this opinion. He states, 'The Vedic ritual contained within themselves the germs of drama, yet there are nothing but elements of representation. ${ }^{5}$ Most probably dancing and singing were regarded as important features of ritual performances. Practice of various forms of performing arts in the socio-economic life of people has been traced in ancient Indian literature. 'In Vedic period, music and dance can be divided mainly under two heads; ritual and secular/ social. ${ }^{6}$

\section{Professional Artistes}

The Vedic literature mentions some professional singers, e.g. Kāru (Rgveda, 9.112.3), Jaritā and Sūta (Atharvaveda, 5.11.8, Vājasaneyīsamihitā (6.18) and Gāyana (Gopathabrāhmaṇa, 1.1.9). Rgveda also refers to professional dancers (1.192.4). References to dancing and singing suggest that music and dance performances were held in solo (Rgveda, 1.83.6, 1.92.4, 10.71.11.), duet (Rgveda, 6.63.5, Atharvaveda, 5.12.7) sometimes in chorus (Rgveda, 1.6.6, 1.7.1, Atharvaveda, 4.1.15) form also. ${ }^{7}$ Atharvaveda (2.36.1) also refers to public dance of women. Such women were known by the general term Națī, or Nātakīyā.8 Nātyaśāstra also refers to them. Bharata's Nātakīyā was a professional artiste who received proper training under the guidance of an Ācārya. According to the definition of Bharata, 'Women who have physical beauty, good qualities, generosity, feminine charm, patience, and good manners, and who possess soft, sweet and charming voice, and varying notes in her throat, and who are experts in representation of passion, and feeling, know well of representation of the temperament, have sweetness of manners, are skilled in playing musical instruments, have a knowledge of notes, Tâla and Yati are associated with the master for the dramatic art, clever, skilled in acting, capable of using reasoning positive and negative, and have youthful age with beauty, are known as actresses (Nāțakīyā). ${ }^{9}$ Later Samihitās refer to women participation in theatrical art especially in music and dance. ${ }^{10}$ The word nata does not occur in Vedic literature. It is found for the first time in Aștâadhyāy $\bar{\imath}$ of Pạnini (4.3.110-111) and there it means pantomime. ${ }^{11}$ Naturally Mahābhāsya (1.4.29) too refers to nața. Post-Vedic literature gives different terms for artistes. Their arts had different forms. Śailūṣa in Taittirīyabrāhmana (III.4.2.1) denotes an actor skilled in the fourfold abhinaya. Śailūṣa is a term often mentioned in many sources in the sense of a dancer. Among the other artistes Śobhanikas were probably pantomimes and Grantikas were recites. Kuśilavas and Kathaka were referred to as actors. ${ }^{12}$ Sailūṣa is mentioned in Rāmayyana in the sense of an actor. ${ }^{13}$ The Rāmāyaña records the performance of dance and drama. ${ }^{14}$ In this connection Nața, Narttaka, Vādaka, and Tālāvacaras are other artistes referred to in Rāmāyana. Ayodhyākāṇ̣̂ (6.14) says that artistes had their own troupes. Mahäbhārata probably contain references much older than the time of its compilation and it refers to a very old tradition of professional artistes i.e. Nața, Narttaka, Malla, Māyāvī, Vaitālika, Sūta, Māgadha etc. ${ }^{15}$ These professional artistes represent a community consisting of artistes from both the classical and folk traditions. ${ }^{16}$ The Buddhist Nikāyas and Jātakas also speak of different types of entertainers. Jātaka stories inform that the family of actors learnt and adopted 
their family-art as their family profession. Actors known from Buddhist literature were mostly folk artistes and they earn money through their art ${ }^{.17}$

In Arthaśāstra, Nața is mentioned as a community or a class. Their art was their profession, as source of their livelihood. Arthaśāstra mentions Kuśílava as actor, and thus it seems that amalgamation of different performing arts has already begun. ${ }^{18}$ It is generally believed that the term is derived from Kuśa and Lava of Rāmāyaṇa of Vālmīki, twin sons of Rāma who sung Rāmāyana for the first time. ${ }^{19}$ According to Nātyaśāstra Kuśilava was an important member of the dramatic troupe who has to organise different instrumentalists. It is on the basis of his capability, deep knowledge and unperturbed serenity he was known as Kuśīlava ${ }^{20}$

A.B. Keith thinks the mode of formation of the compound Kusîlava is strange, in which the first member represents a woman's name. Perhaps it was due to the bad morals of such artistes that later, instead of Kuśalava, they came to be known as Kuśilava (śilla, meaning manners, with prefix ku, denoting of bad morals). ${ }^{21}$ 'The artistes, whose function was to recite the heroic deeds of ancient kings in a dramatic style, came to be known as Kuśilavas, after the twin brothers of Rāmāyana. Formerly they were reciters like later Kathakas but gradually their association with drama deepened and they became known as actors. ${ }^{22}$ In Arthaśāstra they appear as wandering artistes. Bards and dancers

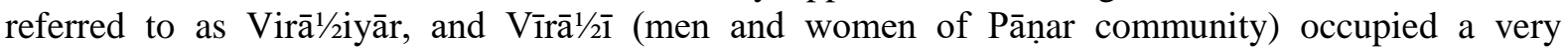
important position in Sangam literature. They were very graceful dancers and appeared as wandering minstrels. ${ }^{23}$ Actors, Dancers, and other professional artistes, both men and women, were viewed with disfavour in the Dharmaśāstras. Thus, all sources prove that in ancient period singing, dancing, acting and other forms of performing arts were practiced not only as forms of entertainment but also as a means of revenue and a livelihood at least by some sects of people.

\section{Notes}

1 Kumkum Roy, Historical Dictionary of Ancient India, Scarecrow Press, United States, 2009, p.86.

2 Iravati, Performing Artistes in Ancient India, DK Print World, New Delhi, 2003,p.11.

3 Ibid, p.2.

4 A.L. Basham, The Wonder that was India, Rupa \& Co., New Delhi, 1997, p.385.

5 A.B. Keith, The Sanskrit Drama in its Origin and Development; Theory and Practice, Motilal Banarsidass, Delhi, 1998, (reprint) pp.23-25.

6 Pranati Ghoshal, Lifestyle of the Vedic People, D.K. Print World, New Delhi, 2006, p.124.

7 Ibid, p.128.

8 Iravati, Performing Artistes in Ancient India, DK Print World, New Delhi, 2003,p.66.

9 See Nātyaśāstra, 34.48-50.

10 See Taittirīyasamhitā, 6.16.5, Maittrāyaṇīsamihitā, 3.7.3.

11 A.B. Keith, The Sanskrit Drama in its Origin and Development; Theory and Practice, Motilal Banarsidass, Delhi, 1998, (reprint) p.31.

12 Iravati, op.cit., p.16.

13 See Rāmāyaṇa of Vālmīkī, 2.8.16, with the commentaries, Tilaka, Siromani and Bhūsana, Śāstri Srinivasa Katti Mudholakara (Ed.), Parimal Publications, Delhi, 1990.

14 Rāmāyaṇa, Ayodhyākāạda, 67.15.

15 Śāntiparvan, 69.60. See also Anuśāsanaparvan (33.12.), Vanaparvan (313.80).

16 Iravati, op.cit., p.37.

17 Ibid.

$18 \mathrm{Ibid}, \mathrm{p} .38$. 
19 A.B. Keith, op.cit., p.31.

20 Nātyaśāstra, 35.106.

$21 \mathrm{Ibid}$.

22 Iravati, op.cit., pp.31-32.

23 See Vijaya Ramaswamy, in Kumkum Roy (Ed.), op.cit., p.161. 